I så måte er fremstillingen bokstavelig talt eksemplarisk. I en innføringstekst som dette er det forståelig nok vanskelig å gå i dybden eller bruke utstrakt plass til å integrere stoffet rundt hukommelsespsykologiens grunnleggende problemstillinger. Noe mer diskusjon av teoretiske forklaringsprinsipper hadde nok gitt mer faglig tyngde. Men forfatteren tar opp mange temaer med kloke kommentarer som gir leseren lyst på mer informasjon - hvilket vel er viktigste målsetting. Hvert kapittel konkluderer hensiktsmessig med henvisning til utfyllende litteratur, slik at eventuell fordypning i stoffet blir opp til leseren.

Karlsen åpner ved å vise til at man i psykologiske forklaringer ofte og i stor grad bruker metaforer for å forklare de studerte saksforhold. Kanskje kunne han i noe sterkere grad gjort leseren klar over at mange av hukommelsens termer og problemstillinger fremdeles er farget av metaforiske forutsetninger, for eksempel «hukommelsesspor», «konsolidering eller svekking av hukommelsesstyrke». Han er flink med illustrerende forklaringer. Faren er at illustrasjoner av diskutable metaforer kan komme til å gi leseren skjeve assosiasjoner. At fremstillingen gir assosiasjoner og grunnlag for egne tanker og ikke bare fungerer som en oppramsende katalog av forskningsdata, er naturligvis meget rosverdig. Hva er hukommelse er hermed varmt anbefalt.

\section{Tore Helstrup}

Psykologisk institutt

Universitetet i Oslo

\section{Kroppen som eksistens og biologi}

von der Fehr D.

Når kroppen tenker

150 s. Oslo: Universitetsforlaget, 2008.

Pris NOK 269

ISBN 978-82-15-01371-8

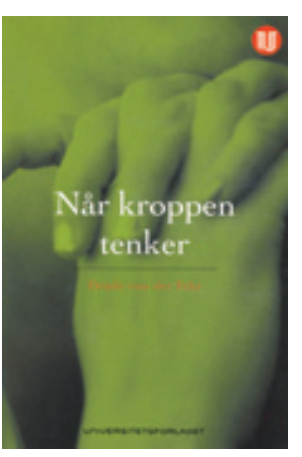

Forfatteren er professor i allmenn litteraturvitenskap og har i de senere år drevet mye med tverrvitenskapelig virksomhet om litteratur og sykdom. Hun angir at hun har skrevet boken for å møte et behov for endring av det medisinske og helsefaglige teorigrunnlaget i retning av en mer helhetlig måte å tenke på.

Innledningsvis beskriver hun sine egne erfaringer med sykdom, behandling og møte med behandlere. Dette ble avgjørende for bokens utforming. Hun gjennomgikk en bakteriell hjernehinnebetennelse, og i forløpet av denne fikk hun i tillegg et hjerneslag. Et hovedpoeng er betydningen av førstepersonserfaringer: I en situasjon der forfatteren var bevisstløs og opplevde å være i livsfare, fornemmet hun musklenes motstand og liv i kroppen. Dette minnet er analysert og bearbeidet i ettertid, og i dag ser hun på det som at kroppsbevisstheten på et lavt bevissthetsnivå var helt på det rene med den fare organismen var i. I refleksjonen over disse erfaringene knytter hun an til ulike teoretikere og argumenterer for å tolke traumatiske erfaringer som en livspraksis med helbredende virkning. Hun understreker at integrasjon av førstepersonserfaringer er viktig i helbredelsesprosessen.

Hovedtemaet er tegnteori og hvordan den kan bidra til å utvide medisinsk teori til å innbefatte pasienters førstepersonserfaringer og slik knytte en forbindelse mellom den eksistensielle og den biologiske kroppen. Innen medisinen er uttrykket «biopsykososial» mye anvendt for å beskrive sykdommers årsaksforhold. Dette tydeliggjør medisinens behov for teoretiske perspektiver som kan bidra til økt forståelse for hva slags sammenhenger det er mellom de biologiske, psykologiske og sosiale aspektene ved mennesket og menneskets lidelser. Forfatteren viser gjennom sju kapitler hvordan tegnteoretiske begreper kan hjelpe oss til å forstå slike sammenhenger. Hun gjør rede for tegnteori, først og fremst Charles Sanders Peirces pragmatiske tegnteori, som handler om hvorledes mennesker og andre levende organismer skaper og utveksler mening gjennom tegn. Et tegn kan defineres som et fenomen som representerer et annet fenomen. Tegnet hjelper oss til å slutte oss frem til noe som ikke er åpenbart. Symptomet diskuteres i lys av tegnteori, og det understrekes at det ved ulike typer tegn er ulike sammenhenger mellom tegnet og det objektet tegnet viser tilbake til.

Disse perspektivene er interessante for helsepersonell og kan gi viktige bidrag til det medisinske og helsefaglige kunnskapsgrunnlaget. Kroppen som eksistens og biologi bidrar bl.a. med teoretisk forankring av førstepersonserfaringer og mening som knyttes til disse. Videre gir symptomet i en tegnteoretisk kontekst meg som lege $ø k t$ forståelse for diagnose og diagnostikk. Jeg opplever imidlertid det tegnteoretiske begrepsapparatet som vanskelig tilgjengelig. Muligens ville flere konkrete eksempler ha hjulpet. Også beskrivelsen av symptomet som tegn er vanskelig å forstå, for eksempel sammenhengen mellom kroniske muskelsmerter som et tegn (betegnende indeks) og kroppslige forhold. Et supplerende fysioterapeutisk perspektiv kunne lettet forståelsen for mulige sammenhenger mellom smertene og den konkrete kroppen, for eksempel Thornquist (1) og Engelsrud (2).

Sissel Steihaug SINTEF

Litteratur

1. Thornquist E. Å se på kroppen med nye øyne. Tidsskr Nor Lægeforen 1992; 112: 919-21.

. Engelsrud G. Kvinner i bevegelse mellom lengsel og lyst. Arbeidsnotat 4/1997. Rev. utg. Oslo: Senter for kvinneforskning, Universitetet i Oslo, 1997.

\section{Grunnbok i holdninger}

Lauveng A.

Arbeidsmaur med gipset hjerte

211 s. Oslo: Universitetsforlaget, 2008.

Pris NOK 299

ISBN 978-82-15-01224-7



Psykisk lidelse er et av de viktigste forholdene knyttet til arbeidsuførhet og behov for tilrettelegging $i$ arbeidslivet. Tema for denne utgivelsen er forståelse av attføringsprosessen når man har psykiske vansker. Økt kunnskap om psykisk helse og arbeidsliv er en målsetting for forfatteren, som også er psykolog og en ettertraktet foredragsholder.

Arnhild Lauvengs selvbiografiske bok I morgen var jeg alltid en løve (2005) er allerede blitt et referanseverk om psykisk lidelse. Hun har også utgitt Unyttig som en rose (2006).

Arbeidsmaur med gipset hjerte er en anskueliggjøring av hva psykisk lidelse og belastende livserfaringer kan innebære av begrensninger, utfordringer, komplikasjoner og kommunikasjonsvansker, både for den det gjelder og for dem som står rundt og forsøker å hjelpe.

Den omhandler ulike aspekter ved psykisk lidelse og arbeidsliv i en nærgående og eksistensiell form. Språket er klart, personlig og lyrisk. Forfatteren bruker virkningsfullt illustrasjoner fra så vel psykologisk teori som eget liv og jordnære metaforer, der «maur eller barnål»» er hovedmetaforen. Andre eksempler på lettfattelig formidling er diagnosekapitlet med overskriften I hvert fall er det sikkert at det kanskje er ei ku, kapitlet om å bygge en ny karriere - Sparkling av luftslott - og kapitlet om tillitsbygging, som innledes med Sjeler bør oppbevares frostfritt.

I forståelsen av psykisk lidelse opplever vi for tiden et paradigmeskifte i teoretisk og praktisk tilnærming. Bevegelsen går fra en inndeling $i$ «oss» (de friske) og «dem» (de syke) til en dimensjonal og allmenn- 
menneskelig modell. Lauvengs arbeider er også et uttrykk for dette. Arbeidsmaur med gipset hjerte kan leses som en konkret veileder i attføringsprosessen, men representerer også en grunnbok i holdninger til psykisk lidelse.

Den er så sentral og så godt skrevet at den egner seg for alle med interesse for psykisk lidelse. Målgruppen er i utgangspunktet arbeidstakere og deres omgivelser $\mathrm{i}$ arbeidslivet, fra kolleger til NAV-ansatte. Denne utgivelsen er selvfølgelig nyttig og tankevekkende også for spesialisthelsetjenesten.

\section{Vrøvl om besettelse og ingenting om avhengighet}

\section{Dysthe P.}

\section{Besettelsen}

En historie om avhengighet. 219 s. Oslo Cappelen Damm, 2008. Pris NOK 329

ISBN-978-82-04-14287-0

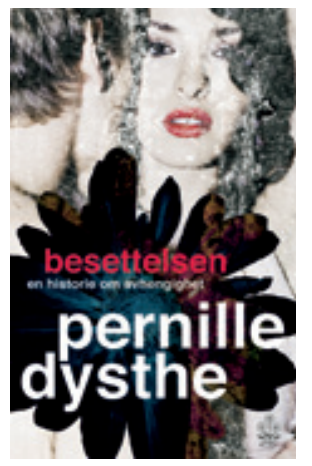

Av og til angrer man på at man har sagt ja til å skrive en anmeldelse. Man bør jo yte boken rettferdighet ved å lese den, ikke bare skumme her og der, men lese den fra perm til perm. Det er jo flaut hvis man uttaler seg negativt om en utgivelse som viser seg å ha et poeng - et punkt som snudde det hele fra uforklarlig smørje til poengtert mening. Denne anmeldelsen angret jeg på etter å ha lest vaskeseddelen. Og ikke på noe tidspunkt, i løpet av de 217,5 påfølgende sidene, lot jeg være å angre. Jeg angret fra perm til perm.

Det kom ikke noe poeng. Ingenting snudde dette. Ingenting brakte dette opp fra et flaut lavmål. Her er det bare et enormt ordgyteri om trivialiteter og uinteressante ting. Og verre enn det - nokså alvorlige ting, ting som betyr noe for folk, blant annet relasjoner og sex, blir gjort trivielt og uinteressant. Det gjøres gjennom å slenge ut tabuord og banale frekkaserier ustanselig. Besettelsen skal angivelig handle om avhengighet av Internett-sjekking. Tro meg - den handler ikke om noe som kan minne om avhengighet engang. Kan man bli avhengig av Internettsjekking? Her får vi ikke engang reminisenser av et svar. «Treffsikkert og på hudløst og humoristisk vis skildres menneskelige [...] mutasjoner anno 2008. [...] Nettsjekking blir ikke det samme etter dette,» står det på vaskeseddelen. Dette skulle illustrere hvilket sludder vi snakker om. Styr unna!

\section{Jørgen G. Bramness}

Senter for rus og avhengighetsforskning (SERAF) Universitetet i Oslo

\section{Men sykdommene mine får du aldri}

Hofmann B.

Hva er sykdom?

205 s, tab, ill. Oslo: Gyldendal Akademisk, 2008. Pris NOK 265

ISBN 978-82-05-35938-3

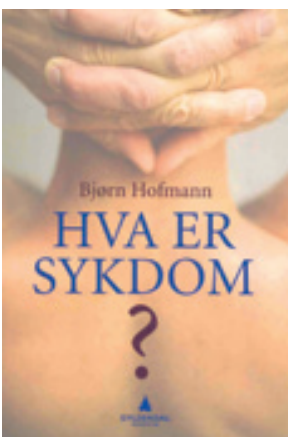

Bjørn Hofmann har skrevet en god bok om et umulig spørsmål: Hva er sykdom? I motsetning til helsebegrepet, som ganske ofte blir gjenstand for utførlige begrepsmessige utlegninger, blir sykdomsbegrepet sjelden drøftet på samme

måte. Til tross for at det, som Hofmann påpeker, står helt i sentrum av den medisinske praksis.

Teksten er en kontinuerlig problematisering av sykdomsbegrepet. Hva er det som kjennetegner en sykdom? Skal sykdom forstås som en ting i naturen, som et begrep eller som en sosial konstruksjon? Defineres den av sine årsaker, som en blanding av tegn og symptomer eller som forstyrret balanse? Eller er sykdom å forstå som avvik fra en norm? Kan verdi og fakta skilles når vi snakker om begrepet sykdom? Det er ganske mange fine og systematiske diskusjoner av disse spørsmålene, som hittil har vært lite fremme i den norske medisinske samtalen. Men hvem er teksten skrevet for?

Forordet tar en obligatorisk runde til målgruppen - som er medisinstudenter og mastergradstudenter innen ulike helsefag. Hofmann mener at sykdomsbegrepet er relevant for all medisinsk praksis. Til det formål har han og forlaget laget en bruksbok - uten noteapparat og med mange eksempler. Eksemplene er stort sett gode, med noen unntak (hvorfor kunne ikke forlaget spandert en medisinsk korrekturleser): Dendritt er ikke en sykdom (s. 9), men en anatomisk struktur, og man har ikke sluttet å gjøre angiografi ved spørsmål om myokardiskemi (s. 152).

Men hvor vellykket er ambisjonen om «å vise hvor relevant filosofien er for forståelse og utøvelse av helsefag»? De fleste medisinere er pragmatikere - og forholder seg ikke til slike filosofiske spørsmål. Deres sykdomsbegrep er intimt forbundet med kasus i praksis, og det er vanskelig å la en abstrakt diskusjon bli relevant for denne praksisen. Som Hofmann selv sier det: «Helsefaglig kunnskap er knyttet til handling: Vi vil vite for å hjelpe.» $\mathrm{Og} H v a$ er sykdom? gir ikke kunnskap til å hjelpe i hvert fall ikke umiddelbart. Men for den som vil se sitt fag i en større sammenheng, få et perspektiv på det de gjør, er den helt avgjørende. Jeg tror denne utgivelsen derfor først og fremst vil være av interesse for dem som i utgangspunktet er opptatt av eller arbeider med relaterte problemstillinger. For dem blir mangelen på noteapparat og eksplisitt diskusjon med den eksisterende litteratur utilfredsstillende - en mer inngående posisjonering ville ha gjort argumentasjonen klarere. I stedet omtaler Hofmann sin posisjon ved hjelp av termer som «vi» og «oss» - uten at det blir klart hvem det er (noen ganger er det «vi helsepersonell», andre ganger «vi forskerkollegium», dvs. Bjørn Hofmann selv).

På den annen side: For den interesserte leser finnes det her rikelig av stoff man kan begynne med hvis man ønsker å vite mer om hva «sykdom» er, og den utførlige litteraturlisten gir henvisning til videre studier. Alt $i$ alt er dette en utgivelse vi trengte i Norge, og forfatteren har gjort et imponerende stykke arbeid ved å vise hvordan sykdomsbegrepet unndrar seg all definisjon. Snarere enn å vise hvor relevant begrepet er i praksis, viser han hvor umulig det er å snakke om «sykdom» som noe enhetlig håndterbart. Som han selv sier: «Problemstillingens relevans avhenger av hvilket perspektiv man har.» Etter dette kan ingen med hånden på hjertet si at de vet hva sykdom er!

\section{Anne Kveim Lie}

Berlin

\section{Ellisif Wessel - myter og menneske}

Wikan S.

Ellisif Wessel

En biografi. 360 s, ill. Oslo: Pax, 2008.

Pris NOK 398

ISBN 978-82-530-3141-5

Den eksentriske Ellisif Wessel

(1866-1949) er antakelig norgeshistoriens mest berømte doktorfrue - kjent for den hun var og det hun gjorde, men også gjennom utallige myter og historier. For venstresiden i norsk politikk er hun et ikon. Blant fotografer har hun en etablert posisjon som folkelivsskildrer. Hennes tekster og dikt kan fortsatt leses med utbytte. Kombinasjonen av personlighet, tid, sted og til- 